\title{
Primary Closure of Infected Wound Infested by Fly Larvae-Case Report in Dog
}

\author{
Leonardo Martins Leal* ${ }^{*}$, Guilherme Mantuani Silva, Carla Nazaré Magalhães, \\ Danielli Aparecida Lavelli, Joseneia Boeing, Amanda Marcondes Pires, \\ Caroline Naiade Tavares, Erica de Andrade Seidemann, Beatriz Dellalatta de Sá \\ Department of Veterinary Medicine, Ingá University Center (UNINGÁ), Maringá, Brazil \\ Email: *leonardo.vet@hotmail.com
}

How to cite this paper: Leal, L.M., Silva, G.M., Magalhães, C.N., Lavelli, D.A., Boeing, J., Pires, A.M., Tavares, C.N., de Andrade Seidemann, E. and de Sá, B.D. (2019) Primary Closure of Infected Wound Infested by Fly Larvae-Case Report in Dog. Open Journal of Animal Sciences, 9, 297-304. https://doi.org/10.4236/ojas.2019.93025

Received: April 27, 2019

Accepted: June 25, 2019

Published: June 28, 2019

Copyright $\odot 2019$ by author(s) and Scientific Research Publishing Inc. This work is licensed under the Creative Commons Attribution International License (CC BY 4.0).

http://creativecommons.org/licenses/by/4.0/

c) (i) Open Access

\begin{abstract}
One of the most common aggravating factors of wounds is the myiasis. Flies lay their eggs on the wound, they hatch and release a larval form of the dipteran, which feeds on host tissues leading to necrosis and large production of exudate, thus, it is an extremely pleasant environment to bacterial multiplication. The aim of this study was to describe the case of a dog that displayed an infested larvae ulcerated tumor in the ocular region. Successful results were obtained when performing surgical treatment of the wound with healing by primary closure. The 13-year-old female dog, $30 \mathrm{~kg}$, was brought to the Veterinary Clinic of Ingá University Center, Maringá-PR, Brazil, with the main complaint of an ulcerated left ocular tumor. The owner could not tell when the problem had started. After the patient's physical and laboratory evaluation, which were within normal parameters, enucleation was scheduled for tumor removal. On the day of surgery, the owner reported large mucopurulent secretion and foul odor at the site. The patient was taken for the larvae removal surgical procedure and later enucleation. The wound was debrided and washed with physiological solution, and then tarsorrhaphy was performed and a Penrose drain was applied. The animal returned 15 days later with the wound fully healed. As a conclusion with the current report, the primary closure treatment with the use of drain after intense debridement of a fly larvae infected wound can be a good alternative, especially when it is aimed at faster healing.
\end{abstract}

\section{Keywords}

Drain, Enucleation, Reconstructive Surgery

\section{Introduction}

Cases concerning the occurrence of wounds in small animals are frequent in the 
routine of the veterinarian; therefore it is necessary that the professional has a wide knowledge about different types of treatments that can be used. According to Monteiro et al. (2007) [1], cutaneous wounds are defined as any interruption of skin continuity and can be caused by a number of factors including running-over, fights, surgical incisions, burns, falls, and maltreatment.

The most accepted aspects for classification of a wound are the degree of contamination, the causal agent and the degree of tissue compromise. As for contamination, the wound can be: Clean, when surgically created under aseptic conditions; clean-contaminated, when it also occurs in aseptic surgical conditions, but with great potential of contamination, as in enteric surgeries for example; contaminated, with an average between zero and six hours of occurrence; and infected, wounds exposed for a long period to contaminants and are characterized by the presence of exudates, devitalized tissues, foreign bodies and pus. As for the causal agent, wounds are divided into: Incised or surgical, caused by a cutting object as scalpel or knife; bruises, caused by blunt objects; lacerations, when there is tissue loss originating irregular borders; and puncture, originated through a pointed object such as a teeth. Regarding tissue compromise; it is defined in stages: Grade 1, attachment of the epidermis; Grade 2, with the involvement of the epidermis and dermis; Grade 3, involves epidermis, dermis and subcutaneous; and Grade 4, an intense injury involving bones and muscles [2] [3] [4] [5].

The healing process of a wound is dynamic and controlled by various physiological phenomena involving physical, chemical, cellular events, growth factors, matrix components, blood components, among several others, in order to completely restore the injured tissue. This process can be divided into 4 phases: Inflammatory phase; debridement phase; proliferative phase and maturation phase [2] [3] [4] [5].

There are three methods that can be used for wound healing, the primary closure method is to approach the edges of the wound using suture techniques, this method is appropriate for recent injuries, with little tissue loss, and minimal contamination; second intention: A method that allows the wound to heal open through contraction and epithelialization, it is used for highly contaminated and infected injuries, and with intense tissue loss where it is impossible to approach the edges; secondary closure: This method requires an open previous treatment of the wound until occurs granulation tissue formation, and then undergoes surgical suture, indicated for infected wounds [3] [5] [6].

One of the most common aggravating factors of wounds is the myiasis. Flies lay their eggs on the wound, they hatch and release a larval form of the dipteran, which feeds on host tissues leading to necrosis and large production of exudate, thus, it is an extremely pleasant environment to bacterial multiplication. The event occurs mainly due to the neglect of wound care, such as lack of hygiene and absence of bandage [7] [8].

Therefore, the aim was to describe the case of a dog affected with fly larvae infected wound caused by an ulcerated tumor in the ocular region. Obtaining 
successful results when performing wound treatment with primary closure.

\section{Case Report}

A 13-year-old female dog weighing $30 \mathrm{~kg}$ displaying an ulcerated tumor in left ocular (Figure 1) was brought to the Uningá Veterinary Clinic in Maringá, Paraná, Brazil. The owner didn't inform when the condition had started. After clinical and laboratory evaluation, with results within the parameters of normality, enucleation was scheduled for tumor removal. The owner was advised to clean the patient's eye with $0.9 \% \mathrm{NaCl}$ physiological solution every six hours conjointly, Ranitidine (2.2 mg/kg, BID ["bis in die"], 15 days), Cephalexin (30 $\mathrm{mg} / \mathrm{kg}, \mathrm{BID}, 15$ days), Tramadol Hydrochloride (3 mg/kg, TID [“ter in die"], 7 days) and Meloxicam ( $0.1 \mathrm{mg} / \mathrm{kg}$, SID [“semel in die"], 5 days) were prescribed. The use of the Elizabethan collar was also recommended.

On the day of surgery, five days after veterinary appointment, the owner reported large mucopurulent discharge and foul odor on the left eye region. When asked about the previously recommended treatment, the owner stated he had done nothing.

After clinical evaluation, the presence of myiasis (fly larvae) was observed. The larvae had spines at the end of the body and pigmented and elongated tracheal trunks. Therefore, we supposed that was Cochliomyia hominivorax fly larvae. Capstar $^{\circledR}$ (Nitenpyram-NOVARTIS) was prescribed in a single oral dose and the patient was forwarded for surgical removal of the larvae and then enucleation.

Under general anesthesia with Propofol $(5 \mathrm{mg} / \mathrm{kg}$, IV, induction, and 0.04 $\mathrm{ml} / \mathrm{kg} / \mathrm{min}$ of continuous infusion), the larvae were removed, the enucleation was performed, the wound was abundantly debrided and washed with $0.9 \%$ sodium chloride $(\mathrm{NaCl})$ solution $(300 \mathrm{ml} / \mathrm{kg})$. Tarsorrhaphy was performed with nylon (3-0) in a single interrupted pattern and a Penrose drain was used (Figure 2).

Ranitidine $(2.2 \mathrm{mg} / \mathrm{kg}, \mathrm{BID}, 15$ days), Cephalexin (30 mg/kg, BID, 15 days), Tramadol Hydrochloride $(4 \mathrm{mg} / \mathrm{kg}$, TID, 5 days $)$ and Meloxicam $(0.1 \mathrm{mg} / \mathrm{kg}$,

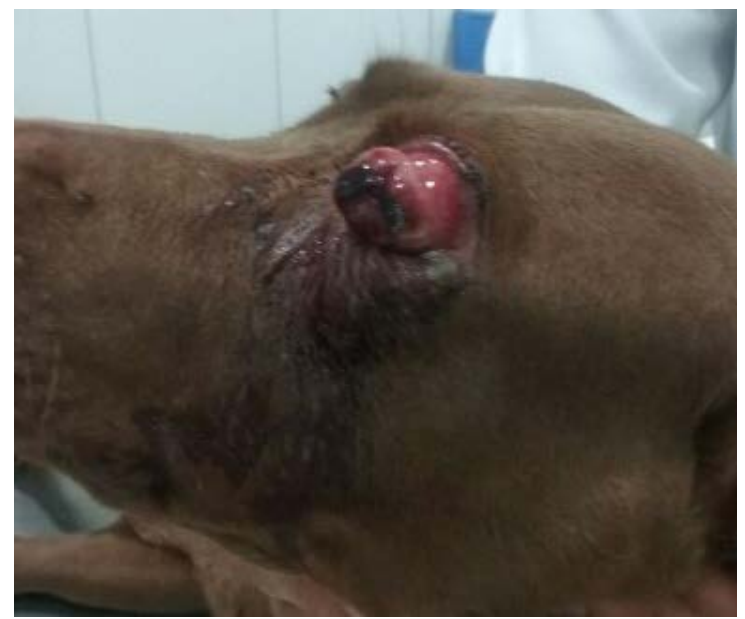

Figure 1. Photographic image of female dog, Labrador Retriever, 13 years old, $30 \mathrm{~kg}$, displaying ulcerated tumor in the left eye. 
SID, 5 days) were prescribed again. The wound was cleaned every 6 hours with $0.9 \% \mathrm{NaCl}$ physiological solution and the use of Elizabethan collar was recommended. The drain detached from the wound in two days after the surgery and stitches were removed 10 days after the surgical procedure. The patient returned after 15 days, with the wound healed (Figure 3). After 60 days, the patient owner

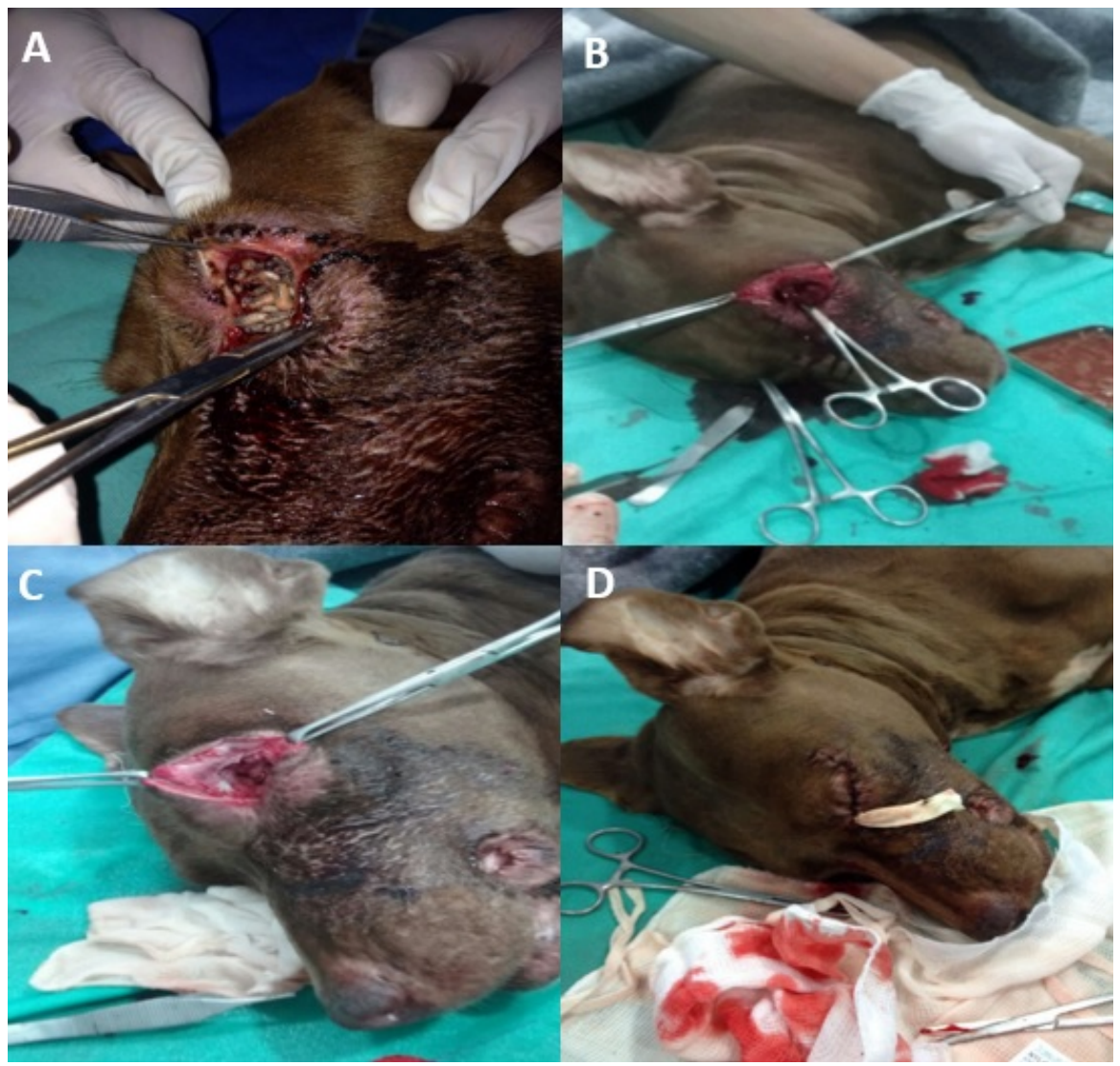

Figure 2. Photographic image, Labrador Retriever, 13 years old, $30 \mathrm{~kg}$, trans-operative removal of larvae and enucleation. (A) Intraocular larvae; (B) Removal of larvae and enucleation; (C) Debridement; (D) Tarssorraphy with Penrose drain.

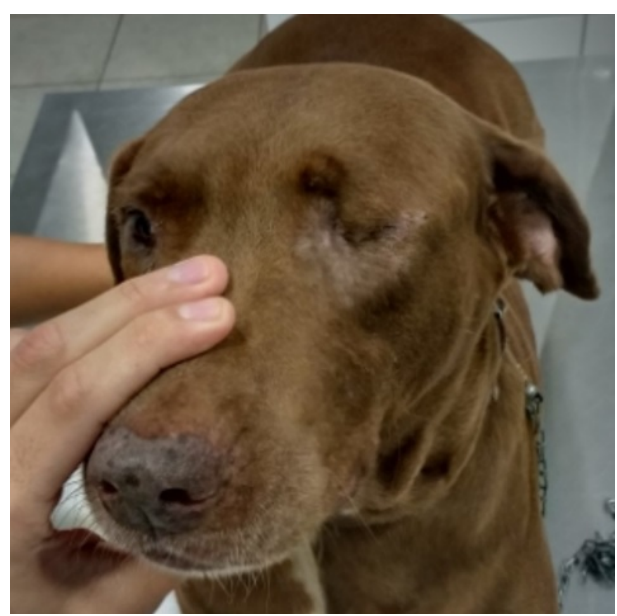

Figure 3. Photographic image of female dog, Labrador Retriever, 13 years old, $30 \mathrm{~kg}$, after 15 days of larvae removal procedure and enucleation. Note the healed wound. 
was contacted for a phone. He describes that your bitch was in perfect conditions and the wound was healed without complications.

\section{Discussions}

Myiasis is caused by Cochliomyia hominivorax larvae and affects humans and animals, occurring with a higher incidence in underdeveloped countries where, most of the time, they are associated with poor hygiene and poor care of exposed wounds. To prevent myiasis, according to Arias et al. (2008) [9], it is necessary to control the fly mainly in endemic areas, in addition to basic health care, hygiene and avoiding the exposure of wounds and injuries. Therefore, due to the dog's owner socioeconomic issues, the development of myiasis in the ulcerated ocular neoplasia displayed by the patient is justified.

Capstar $^{\circledR}$ (Nitenpyram-NOVARTIS) at a dose of $1 \mathrm{mg} / \mathrm{kg}$ to $2 \mathrm{mg} / \mathrm{kg}$ in a single oral dose is very effective as a larvicide of $C$. hominivorax flies and has no adverse events [10]. In this patient, Nitenpyram was used to promote the larvae death and ease their removal in a surgical manner. The dose used in question was $1.9 \mathrm{mg} / \mathrm{kg}$, which provided the desired effect without any adverse reaction.

According to Goes et al. (2012) [11], enucleation is a recommended procedure in cases of ocular perforations, optic nerve rupture, severe trauma, pan-ophthalmites, and ocular neoplasias. Due to significant and traumatic aesthetic changes in many animals and consequences in their owners, the use of acrylic resin or silicone prostheses placed in the ophthalmic cavity after enucleation prior to tarsorrhaphy to improve animal esthetics may be adopted [11] [12] [13]. However, due to the high degree of contamination of the region, the use of any prosthesis was ruled out in order to avoid the persistence of local infection by the production of bacterial biofilm around the prosthesis [14] [15].

Goes et al. (2012) [11], also states that in the enucleation postoperative period, the use of antibiotics, anti-inflammatories, and analgesics is essential. The patient received such medications as described, along with surgical wound care that included local cleaning and the use of Elizabethan collar to avoid trauma.

Magalhães et al. (2001) [16] and Pinto et al. (2007) [17], affirm that the histopathological examination is extremely important in the diagnosis of neoplasias, in the choice of treatment and in determining of the patient's prognosis. Its main advantage lies in the preservation of tissue architecture, necessary for determinating the different types of neoplastic tissue. The fragment for the analysis was indicated and collected, however, due to financial reasons, the owner refused to carry on the procedure.

Healing by primary closure is a method used to treat wounds with close edges, little tissue loss and minimum contamination (about 6 to 8 hours of occurrence), and it is possible to approach the edges by suturing after good antisepsis, accelerating the scarring process [4] [18] [19]. The second intention healing process is more routinely used in cases of extensive wounds where there is a significantly greater tissue loss, with the presence of foreign bodies and evident signs of con- 
tamination, resulting in a slower and more complicated scarring process [2] [5] [18] [19] [20]. However, even knowing that the wound in question was potentially infected, primary closure treatment was chosen aiming a faster wound healing, since the owner was initially neglectful regarding the care related to the daily cleaning of the ulcerated neoplasia. As the patient would already be submitted to the enucleation procedure due to neoplasia, after the larvae were removed, enucleation and surgical debridement, a Penrose drain was placed in order to allow the drainage of possible inflammatory and purulent contents in the postoperative period, avoiding the persistence of possible bacteria that were not totally eliminated with the debridement and local cleaning [6] [18] [19] [21] [22].

Although the primary closure treatment of highly contaminated wounds is controversial in the literature [4] [5] [6] [22] [23], the patient's treatment was successful. Suggesting that the success of this treatment was the association between large surgical debridement followed by abundant cleaning and drain placement [2] [18] [19] [21] [23]. In addition, second-intention healing in this patient would require time, dedication and care for the animal over a long period of time, as the owner had already demonstrated; he did not meet these requirements. Lack of wound care could lead to larger complications such as recurrence of myiasis, osteomyelitis of the orbit and ascending neurological infection.

According to Simas (2010) [4] and Lopes (2016) [19], drains are used for removing fluid in contaminated wounds, reducing the risk of infection and suture dehiscence. The drains are useful, as well as in obliteration of dead spaces, common occurrences after reconstructive techniques. The drains are removed from two to five days and the orifice heals later by the second intention. The drains are divided into two types, active drains that use a vacuum system to perform the drainage, being more used in contaminated and deep wounds, having applicability in any region of the body. However, the use in the case in question was passive or Penrose drain, in which drainage occurs through gravity, routinely used in superficial injuries [6] [19] [22].

\section{Conclusion}

To conclude, the primary closure treatment of fly larvae infected wounds with surgical debridement, abundant cleaning and drainage can be a good alternative, especially when it is aimed at faster healing.

\section{Conflicts of Interest}

The authors declare no conflicts of interest regarding the publication of this paper.

\section{References}

[1] Monteiro, V.L.C., Coelho, M.C.O.C., Carrazzoni, P.G., Mota, R.A., Melo, F.A.D., Cervalho, E.C. and Andrade, L.S.S. (2007) Cana-de-açúcar no tratamento de feridas 
cutâneas por segunda ou terceira intenção. Medicina Veterinária, 1, 1-8.

[2] Trindade, J.T. (2009) Uso de cirurgia reconstrutiva no tratamento de feridas cutâneas abertas em cães e gatos. Monografia (Graduação), Faculdade de Veterinária, Universidade Federal do Rio Grande do Sul, Porto Alegre, 29f.

[3] Mendonça, J.P. (2009) Estudo histopatológico da ação do plasma rico em plaquetas, associado ou não ao laser de baixa potência, na cicatrização por primeira intenção, em ratos wistar. Dissertação (Mestrado), Universidade Federal do Mato Grosso do Sul, Campo Grande, $82 \mathrm{f}$.

[4] Simas, S.M. (2010) O tratamento de Feridas cutâneas em cães e gatos. Monografia (Graduação), Faculdade de Veterinária, Universidade Federal do rio Grande do Sul, Porto Alegre, $112 \mathrm{f}$.

[5] Marceu, R.H. (2010) Cicatrização cutânea por segunda intensão em pequenos animais. Monografia (Graduação), Faculdade de Medicina Veterinária e Zootecnia, Universidade "Júlio de Mesquita Filho", Campus de Botucatu, Botucatu, 23f.

[6] Pavletic, M. (2018) Atlas of Small Animal Wound Management and Reconstructive Surgery, 4th Edition, Wiley-Blackwell, Iowa, $880 \mathrm{p}$.

https://doi.org/10.1002/9781119267539

[7] Cansi, E.R. and Demo, C. (2011) Ocorrência de miiases em animais de companhia no Distrito Federal, Brasil. Acta Scientiae Veterinariae, 39, 982.

[8] Teixeira, D.G. (2013) Cochliomyia hominivorax (coquerel, 1858) (diptera: calliphoridae): Características e importância na medicina veterinária. Dissertação (Mestrado), Escola de Veterinária e Zootecnia, Universidade Federal de Goiás, Goiânia, 37f.

[9] Arias, M.V.B., Battaglia, L.A., Aiello, G., Carvalho, T.T. and Freitas, J.C. (2008) Identificação da suscetibilidade antimicrobiana de bactérias isoladas de cães e gatos com feridas traumáticas contaminadas e infectadas. Semina: Ciências Agrárias, 29, 861-874. https://doi.org/10.5433/1679-0359.2008v29n4p861

[10] Cardozo, S.V. and Ramadinha, R.R. (2007) Avaliação do tratamento de miíases em cães através da utilização do nitenpyram. Revista brasileira de Ciência Veterinária, 14, 139-142. https://doi.org/10.4322/rbcv.2014.250

[11] Goes, L.D., Risseti, R.M., Dias, F.G.G., Pereira, D.M. and Dias, L.G.G.G. (2012) Técnica de enucleação-Revisão de literatura. Revista cientifica eletrônica de medicina veterinária, 9,5 .

[12] Oria, A.P., Neto, F.A.D., Junior, D.C.G., Pinna, M.H. and Laus, J.L. (2011) Utilização de implantes para o manejo de cavidades anoftálmicas. Medicina Veterinária, 5, 1-12.

[13] Ribeiro, A.R.B. (2013) Causas de enucleação, evisceração e exenteração em pequenos animais-Estudo retrospectivo 2002-2012. Dissertação (Mestrado), Faculdade de Medicina Veterinária, Universidade de Lisboa, Lisboa, 82f.

[14] Vestre, W.A., Brightman, A.H. and Helper, L.C. (1978) Use of an intraocular prosthesis in the cat. Feline Pract, 8, 23-26.

[15] Rahal, S.C., Schellini, S.A., Marques, M.E.A. and Ranzani, J.J.T. (2000) Emprego de prótese intraocular de resina acrílica. Estudo experimental em ratos. Brazilian Journal of Veterinary Research and Animal Science, 37, 286-290. https://doi.org/10.1590/S1413-95962000000400004

[16] Magalhães, A.M., Ramadinha, R.R., Barros, C.S.L. and Peixoto, P.V. (2001) Estudo comparativo entre citopatologia e histopatológica no diagnóstico de neoplasias caninas. Pesquisa Veterinária Brasileira, 21, 23-32. https://doi.org/10.1590/S0100-736X2001000100006

[17] Pinto, J.P., Teixeira, L.B.C. and Junior, A.R.S. (2007) Estudo histopatológico e 
histoquímico de mastocitomas na região de espirito santo do pinhal. Revista Acadêmica, 5, 265-276. https://doi.org/10.7213/cienciaanimal.v5i3.10104

[18] Vitor, M.R.C. (2015) Proposta de uma escala para avaliação do processo de cicatrização de ferida cirúrgica no cão e no gato. Dissertação (Mestrado), Faculdade de Medicina Veterinária, Universidade de Lisboa, Lisboa, 70f.

[19] Lopes, M.A.I. (2016) Abordagem e manejo médico-Cirúrgico de feridas abertas em cães e gatos: Caracterização etiológica e estudo de padrões traumáticos. Dissertação (Mestrado), Faculdade de Medicina Veterinária, Universidade de Lisboa, Lisboa, $110 \mathrm{f}$.

[20] Maruo, W.Y.G. (2007) Tratamento de feridas. Monografia (Graduação), Faculdade de Ciências Biológicas, Universidade Tuiuti do Paraná, Curitiba, $31 f$.

[21] Scheffer, J.P., Atallah, F.A., Estupñan, C.G.O.F.T., Silva, S.J.Q., Silva, T.I.R., Vale, D.F. and Oliveira, A.L.A. (2013) Cirurgia reconstrutiva no tratamento de feridas traumáticas em pequenos animais. Revista Brasileira de Medicina Veterinária, 35, 70-78.

[22] Macphail, C. (2014) Cirurgia do sistema tegumentar. In: Fossum, T., Ed., Cirurgia de pequenos animais, Elsevier, Rio de Janeiro, 190-288.

[23] Leal, L.M. and Martins, A.R.C. (2014) Afecções cirúrgicas emergências em pequenos animais: guia prático para clinico de cães e gatos. 1st Edition, MedVet, São Paulo, $158 \mathrm{p}$. 